Fall 1995

\title{
Empowerment Zones: Urban Revitalization Through Collaborative Enterprise
}

\author{
Audrey McFarlane \\ University of Baltimore School of Law, amcfarlane@ubalt.edu
}

Follow this and additional works at: http://scholarworks.law.ubalt.edu/all_fac

Part of the State and Local Government Law Commons

\section{Recommended Citation}

Empowerment Zones: Urban Revitalization Through Collaborative Enterprise, 5 J. Affordable Hous. \& Cmty. Dev. L. 35 (1995)

This Article is brought to you for free and open access by the Faculty Scholarship at ScholarWorks@University of Baltimore School of Law. It has been accepted for inclusion in All Faculty Scholarship by an authorized administrator of ScholarWorks@University of Baltimore School of Law. For more information, please contact snolan@ubalt.edu. 


\title{
Empowerment Zones: Urban Revitalization Through Collaborative Enterprise
}

\author{
Audrey G. McFarlane
}

ENTERPRISE-1: a: a plan or design for a venture or undertaking. b: Venture, Undertaking, Project; esp: an undertaking that is difficult, complicated, or has a strong element of risk. c: a unit of economic organization or activity (as a factory, a farm, a mine); esp: a business organization: FIRM, CompanY, d: any systematic purposeful activity or type of activity. 2: readiness to attempt or engage in what requires daring or energy: a bold energetic questing spirit: independence of thought: INITIATIVE, ENERGY.'

EMPOWER-1: to give official authority to: delegate legal

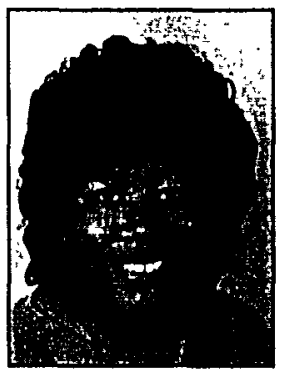

Audrey G. McFarlane

power to: Commission, Authorize. 2: to give faculties or abilities to: ENABLE. ${ }^{2}$

The federal government recently designated six empowerment zones in selected urban areas as an urban revitalization demonstration program. The program is derived from the enterprise zone strategy promoted by former HUD Secretary Jack Kemp that sought to address urban poverty by encouraging business growth through deregulation and tax incentives. The Clinton administration modified the original concept and now refers to the target areas as empowerment zones. As the definitions of "enterprise" and "empower" indicate, renaming the zones reflects a significant shift in emphasis-from a focus on stimulating business enterprise through reducing regulation to one in which regulation is used to enable local governments and communities to devise and implement their own collaborative approaches to human, economic, and community development.

This article reviews the process by which enterprise zones became empowerment zones and the program benefits available to urban empowerment zones. I also discuss the innovative aspects of the program's recent

Audrey G. McFarlane is a visiting assistant professor at the University of Maryland School of Law, where she teaches a seminar and clinic on community development. The article was written while she was an associate with Wilmer, Cutler and Pickering. 
implementation and its implications for significant community participation in planning and development.

\section{Background}

In August 1993 Congress authorized the creation of an urban and rural empowerment zone and enterprise community program as part of the Omnibus Budget Reconciliation Act of 1993 (OBRA). ${ }^{3}$ Passage of this legislation marked the end of more than a decade of unsuccessful attempts by the Reagan and Bush administrations to enact "enterprise zones" as part of a "free market" approach to revitalizing distressed urban areas. OBRA authorized a total of nine empowerment zones and ninety-five enterprise communities-six urban empowerment zones and sixty-five urban enterprise communities ${ }^{4}$ chosen by the Secretary of HUD, and three rural empowerment zones and thirty rural enterprise communities chosen by the Secretary of Agriculture. ${ }^{5}$

Empowerment zones and enterprise communities (all formerly known as enterprise zones) are discrete geographic areas plagued by pervasive poverty, unemployment, and general distress. ${ }^{6}$ They are eligible for targeted application of tax incentives and social service funds to stimulate business creation and expansion and long-term revitalization of the distressed communities. To qualify as an urban zone, the distressed area must not exceed twenty square miles within a city and must meet relatively low population thresholds, not exceeding the lesser of 200,000 in population or 10 percent of the population of the most populous city located within the nominated area (up to 50,000 ). ${ }^{7}$ The aggregate population of all urban empowerment zones cannot exceed $750,000 .{ }^{8} \mathrm{~A}$ rural zone must encompass less than 1,000 square miles and its population cannot exceed 30,000 .

Under the Act, areas designated as empowerment zones are eligible for a number of modest tax incentives to encourage the employment of zone residents through business creation within the zones. Enterprise communities are eligible for only one of the incentives provided under the Act-tax-exempt financing for qualified businesses operating within enterprise communities through state-administered enterprise facility bonds. Empowerment zones and enterprise communities are entitled to a number of other benefits, not the least of which are grants of $\$ 100$ million for each empowerment zone and just under $\$ 3$ million for each enterprise community. ${ }^{10}$ In addition, the Clinton administration has pledged to streamline and improve coordination of federal regulations and other federal programs.

\section{Transformation of Enterprise Zones into Empowerment Zones}

A brief review of the history of enterprise zones is helpful to understand the empowerment zone program and its current prominence in urban policy. The concept is based on an approach adopted in the late 1970s in Great Britain to stimulate industrial activity in London's vacant docklands district through a drastic reduction of taxes and regulation. ${ }^{11}$ Although 
the British did not envision enterprise zones as a means of stimulating economic growth in populated, distressed urban areas, the Reagan administration adopted this approach in the early 1980s as the preferred tool for urban revitalization. ${ }^{12}$ Notwithstanding bipartisan support in Congress, enterprise zone legislative proposals failed repeatedly throughout the 1980 s for a number of complex and disputed reasons. ${ }^{13}$ In 1987 a weak version of enterprise zone legislation was enacted, authorizing the Secretary of Housing and Urban Development to designate 100 severely distressed enterprise zones throughout the United States. ${ }^{14}$ That law, which was never implemented, contained no tax or other financial incentives and relied only on enhanced agency coordination and expedited handling of existing HUD or USDA programs within the zones. ${ }^{15}$

Though unable to obtain support at the federal level, enterprise zones were embraced by most states during the $1980 \mathrm{~s}$ as a method of economic development. First in anticipation of federal enterprise zone legislation and then in the ensuing lack of progress on that legislation, state governments initiated their own versions of enterprise zones, creating a variety of programs with a wide range of incentives available under state powers of taxation or regulation. ${ }^{16}$ According to the American Association of Enterprise Zones, approximately thirty-five states and the District of Columbia now have enterprise zone programs. ${ }^{17}$ Despite congressional inaction, a number of federal agencies voluntarily recognized these state enterprise zone efforts in their program administration and often made state enterprise zones a funding or service priority. ${ }^{18}$

At the national level, the enterprise zone concept received its most significant attention and support during the spring of 1992. In the wake of the Los Angeles riots that followed the Rodney King verdict, the Bush administration advanced the enterprise zone concept as the centerpiece of its response to urban unrest. In 1992 Congress proposed legislation that would have created fifty enterprise zones over four years with a number of tax incentives including: (1) a 15 percent employer wage credit against the first $\$ 20,000$ of wages paid; (2) accelerated depreciation deductions for businesses; (3) a capital gain exclusion and ordinary loss treatment for certain stock in zone-related property; (4) a deduction for the purchase of stock issued by a corporation to purchase property within an enterprise zone; and (5) expanded tax exempt private activity bond financing. ${ }^{19}$ The legislation never became law. The day after losing the 1992 presidential election, President Bush vetoed the bill because additional and unrelated tax concessions attached to the bill would have increased appropriations from $\$ 2.5$ billion to $\$ 28$ billion, ${ }^{20}$ threatening to make Bush appear as if he had once again broken his promise of no new taxes.

During the 1992 campaign, candidate Clinton promised to adopt enterprise zones as a component of his urban agenda. ${ }^{21}$ Once in office, the Clinton administration encouraged enactment of empowerment zone legislation that built from the vetoed 1992 legislation but made significant changes. The original Clinton proposal called for ten empowerment zones (including one Indian reservation) and 100 enterprise communities (sixty- 
five urban, thirty rural, and five Indian reservations) with employer wage credits of 25 percent of the first $\$ 20,000$ in salary (equal to $\$ 5,000$ ) and other provisions included in the vetoed 1992 bill. Clinton's proposal would have expanded the low-income housing tax credit and included credits for employer contributions to savings accounts for residents of empowerment zones. The final legislation adopted by Congress in August 1993 was more modest and included only the employer wage credit, increased section 179 expensing (i.e., accelerated depreciation for certain assets of companies located in empowerment zones), and private activity facility bonds. ${ }^{22}$

\section{Available Benefits}

Areas designated as empowerment zones and enterprise communities are entitled to the following incentives to foster economic development through business expansion into the zones, small business creation, and employment of zone residents:

\section{Expanded Tax Exempt Financing}

The Empowerment Zone Act established a new category of tax-exempt private activity bond-the enterprise zone facility bond-the proceeds of which may be used to finance start-up or existing businesses that locate an office or production facility in an empowerment zone or enterprise community. The enterprise zone bonds are the only tax incentive offered in enterprise communities: " $[t]$ ax-exempt private activity bonds are issued by a state or local government unit, typically an industrial development authority, for the benefit of a business using the financed facility. The interest rate on the bonds will be lower than prevailing market rates for an equivalent financing using taxable debt, by virtue of the benefit the bondholders receive from the tax exemption of the bond interest. ${ }^{\prime 23}$ At least 95 percent of the proceeds of enterprise zone facility bonds must be used to provide a facility for a qualified business operating within the zone. Each business is limited to an aggregate of $\$ 3$ million within any one empowerment zone or enterprise community and $\$ 20$ million with respect to all empowerment zones and enterprise communities. ${ }^{24}$ The potential benefit of this new type of bond is further limited by the fact that the bonds are subject to a state's overall volume cap for private activity bonds. ${ }^{25}$ Therefore, the ability of a business to take advantage of enterprise zone bonds will be limited or determined by the state's other contemplated bond issue commitments.

\section{Empowerment Zone Employment Credit}

Qualified employers engaged in trade, business, or human service delivery in empowerment zones may claim tax credits for wages paid to zone residents. ${ }^{26}$ For the first seven years of the program (through 2001), employers are entitled to a credit of 20 percent of the first $\$ 15,000$ of wages (for a maximum credit of $\$ 3,000$ ) paid to employees who are residents of 
the empowerment zone and who perform substantially all employment services within the zone. In the eighth, ninth, and tenth years, the credit decreases to 15 percent, 10 percent, and 5 percent, respectively. ${ }^{27}$ Generally, an empowerment zone employer also will be allowed to treat training and educational benefits as wages paid and claim the employment credit deduction. ${ }^{28}$ According to one commentator, under the business tax rules the wage credit is more beneficial to corporate rather than noncorporate entities. For noncorporate entities, "no deduction is allowed for the portion of the wages paid or incurred with respect to a qualified zone employee equal to the amount of the empowerment zone employment credit. Thus for sole proprietors, $S$ corporation shareholders, or partners paying federal tax at the top marginal rate of 39.6 percent, the additional benefit of the credit would be only $\$ 1,812$ per employee ( $\$ 3,000$ credit less $\$ 1,188$ of increased tax due to the lost deduction for wages paid). ${ }^{\prime 29}$

\section{Section 179 Expensing}

Under the tax code, businesses are allowed accelerated deductions for certain depreciable investments. An empowerment zone business is entitled to expense up to $\$ 37,500$ of depreciable property that was placed in service during the tax year and meets the following requirements: (1) the property was purchased by the business after the date of the empowerment zone designation; (2) the business began the original use of the property in the empowerment zone; and (3) substantially all of the use of the property is in active conduct of a qualified business in the empowerment zone. ${ }^{36}$ Qualified zone property also includes property that is substantially renovated by the taxpayer. Property is substantially renovated if, during any twenty-four-month period after the zone designation, additions to the property's basis exceed $\$ 5,000$ or an amount equal to the adjusted basis of the property measured at the beginning of the twentyfour-month period. ${ }^{31}$

The empowerment zone tax incentives are limited to qualified businesses operating within the zone. Under the statute, every trade or business of a corporation or partnership must be "the active conduct of a qualified business within an empowerment zone. ${ }^{132}$ This means that businesses operating outside the zone will have to create a separate subsidiary or other affiliated entity within the zone to receive tax incentives. In addition, at least 80 percent of total gross income must be derived from the active conduct of such business within the zone; substantially all of the entity's use of tangible property must be within the zone; substantially all of the services performed by its employees must be performed in the zone; and at least 35 percent of a business's employees must reside in the zone. ${ }^{33}$ Although these requirements probably were intended to ensure that empowerment zone benefits go to empowerment zone businesses, the requirements may be prohibitive for small or start-up service businesses that operate within a zone and employ zone residents. These busi- 
nesses are likely to lack the legal resources to ensure that they modify their organizational structure if their businesses extend beyond zone boundaries.

Interestingly, the rental of residential property does not qualify as a zone business. ${ }^{3 H}$ This exclusion was probably made in an effort to prevent owners of low-income housing from reaping a windfall. In contrast, real estate leasing is a qualified business where leases to qualified zone businesses account for at least 50 percent of a commercial property's gross rental income. ${ }^{35}$ There are a number of other businesses excluded from qualifying for tax incentives, such as private or commercial golf courses, country clubs, massage parlors, hot tub facilities, suntan facilities, racetracks or gambling facilities, liquor stores, or farms (other than certain small farms). ${ }^{36}$ Although many of these facilities are unlikely to be located in an empowerment zone, the exclusion reflects a value judgment as to those businesses that are appropriate for revitalizing a residential community.

\section{Credits for Contributions to Certain Community Development Corporations}

Congress acknowledged the important contributions local CDCs make in community development by establishing a business tax credit for cash contributions supporting the work of designated CDCs. CDCs were invited to apply for designation in March $1994 .{ }^{37}$ In June 1994 HUD designated twenty community development corporations eligible to receive tax deductible contributions. Twelve operate in urban areas, eight in rural areas: ${ }^{38}$

\section{Eligible Urban CDCs}

(1) New Economics for Women, Los Angeles, CA

(2) Marshall Heights Community Development, Inc., Washington, DC

(3) Tacolcy Economic Development Corp. Inc., Miami, FL

(4) Grasp Enterprises, Inc., Atlanta, GA

(5) Bethel New Life, Inc., Chicago, IL

(6) Urban Edge Housing Corp., Boston, MA

(7) Southeast Development, Inc., Baltimore, MD

(8) New Community Corp., Newark, NJ

(9) Bedford Stuyvesant Restoration Corp., Brooklyn, NY

(10) Hough Area Partners in Progress, Cleveland, $\mathrm{OH}$

(11) Free the Children, Inc., Memphis, TN

(12) The Southern Dallas Development Corp., Dallas, TX

\section{Eligible Rural CDCs}

(1) El Pajaro Community Development Corp., Watsonville, CA

(2) Kentucky Highlands Community Development Corp., London, KY

(3) Coastal Enterprises, Inc., Wiscasset, ME

(4) Delta Foundation, Greenville, MS 
(5) Chautauqua Opportunities, Inc., Mayville, NY

(6) North Cambria Community Development Corp., Barnesboro, PA

(7) National Rural Development \& Finance Corp., San Antonio, TX

(8) Virginia Mountain Housing, Inc., Christiansburg, VA

Contributions to CDCs can take the form of outright grants, loans, or long-term equity investments such as general or limited partnerships and must be made before July 1,1999 . Contributors may claim a 5 percent credit annually over a period of ten years for a total credit of 50 percent of the aggregate contribution. ${ }^{39}$ In order for a contribution to be a "qualified CDC contribution," the CDC must designate the contribution as such. ${ }^{40}$ The aggregate amount of qualified contributions each CDC may designate is limited to $\$ 2$ million." In addition, the CDC must use the qualified contributions for low-income assistance that is "designed to provide employment of, and business opportunities for, low-income individuals who are residents of the operational area of the community development corporation" and approved by the HUD Secretary. ${ }^{42}$ Though the statute seems to focus on CDCs that will foster and promote employment and business opportunities, HUD took a very broad view of that goal. The Secretary's invitation for applications required a description of "[h]ow the CDC will create linkages between human development, economic development, and housing development in its operational area. ${ }^{\prime 43}$

\section{Social Services Block Grants}

OBRA also made $\$ 1$ billion available under Title $X X$ of the Social Security Act for grants to states for each empowerment zone and enterprise community $-\$ 100$ million in grants for each urban empowerment zone, $\$ 40$ million for each rural empowerment zone, and approximately $\$ 2.95$ million for each enterprise community. ${ }^{44}$ The grant funds must be used to promote one or more of the following goals: (1) achieving or maintaining economic self-support to prevent, reduce, or eliminate dependency; (2) achieving or maintaining self-sufficiency, including reducing or preventing dependency; and (3) preventing or remedying neglect, abuse, or exploitation of children and adults unable to protect their own interest, and preserving, rehabilitating, or reuniting families. ${ }^{45}$ Some of the suggested program options are drug treatment programs for pregnant women and mothers with children; employment training in construction, affordable housing rehabilitation and public infrastructure; training in entrepreneurial and self-employment skills; after-school programs; support programs that promote home ownership; and transportation services for zone residents to areas of high job grow th outside of the zone. ${ }^{46}$ Designated empowerment zones and enterprise communities may work to achieve or maintain the goals of economic self-support and self-sufficiency by using the social security block grant funds to capitalize revolving or microenterprise loan funds that benefit low-income residents of the designated empowerment zones and enterprise communities. ${ }^{47}$ In addition, the funds may be 
used to create jobs and promote economic opportunity through matching grants, loans, or investments in community development financial institutions. ${ }^{48}$ To the extent that the social security block grant funds are to be used for program options related to economic self-support, they also may be used to purchase or improve land or facilities, make cash payments to individuals for subsistence or room and board, make wage payments to individuals as a social service, make cash payments for medical care, and provide social services to institutionalized persons. ${ }^{49}$ In many, if not most cases, a substantial percentage of the grants will be used to enhance existing, previously underfunded programs for the human development component of the community development equation. ${ }^{50}$ Although a number of admirable programs are eligible for these funds, it is important that they be used to further long-term community development goals.

\section{Improved Federal Coordination and Preferences for Zone Projects}

To coordinate federal support for the empowerment zone program, President Clinton created a Community Enterprise Board comprised of senior federal officials and heads of the various domestic agencies. ${ }^{51}$ The board, lead by Vice President Gore, will focus on working cooperatively with empowerment zones and enterprise communities to overcome regulatory impediments, permit flexible use of existing federal funds, and assist these communities in meeting essential mandates. In addition, under the auspices of the board, federal agencies will give priority to locating or funding complementary projects within empowerment zones and enterprise communities. For example, the Department of Education is supporting the initiative through its Urban Community Service Program, which gives preference to projects carried out by institutions of higher education working jointly with public and private organizations to address problems confronting urban cominunities, such as lack of work force preparation, health care services, economic development, and underperforming school systems. ${ }^{52}$ Empowerment zones and enterprise communities will also receive special consideration in competition for funding under President Clinton's national service program, AmeriCorp, which allows young people to receive college tuition assistance in return for community service, and the Department of Justice's community policing initiative, the COPs program, which funds a higher level of police involvement within communities. ${ }^{53}$ The Small Business Administration is in the process of establishing One-Stop-Capital-Shops to serve as national and regional capital distribution points for underserved communities in the empowerment zones and enterprise communities. Each shop will have a small business microloan program, a small business investment company to provide equity investments, and a business information and development center to provide technical and managerial assistance. ${ }^{54}$

\section{Strategic Planning Through Local Collaboration}

The competitive application process for empowerment zone and enterprise community designation was initiated in January 1994 . State and local 
governments had six months to develop a collaborative strategic plan for revitalizing the area nominated for zone designation. The strategic plan had to incorporate four key principles:

(1) Economic opportunity, including job creation within the community and throughout the region, as well as entrepreneurial initiatives, small business expansion and training for jobs that offer upward mobility;

(2) Sustainable community development, to advance the creation of liveable and vibrant communities through comprehensive approaches that coordinate economic, physical, community, and human development;

(3) Community-based partnerships, involving the participation of all segments of the community, including the political and governmental leadership, community groups, health and social service groups, environmental groups, religious organizations, the private and non-profit sectors, centers of learning, and other community institutions; and

(4) Strategic vision for change, which identified what the community will become and a strategic map for revitalization..$^{55}$

Guided by these broad principles, applicants were required to explain the community's vision for revitalizing the area, identify key needs of the area, and explain how all social services block grant funds would be used to implement components of the strategic plan. According to HUD guidelines, "[t]he people involved in the development of the strategic plan and implementation of the components must represent all who have a stake in the future of each designated area's neighborhoods and the larger community. ${ }^{156}$ Therefore, applicants were also required to describe the planning process and provide evidence that the process was truly inclusive and collaborative by answering questions designed to encourage outreach to and inclusion of the disparate groups and interests with stakes in the community. For example, applicants were required to:

(1) ... describe the specific groups, organizations, and individuals participating in the production of the plan and describe the history of these groups in the community;

(2) Explain how participants were selected and provide evidence that the participants, taken as a whole, broadly represent the racial, cultural, and economic diversity of the community;

(3) Describe the role of the participants in the creation, development, and future implementation of the plan;

(4) Identify two or three topics addressed in the plan that caused the most serious disagreements among participants and describe how those disagreements were resolved;

(5) Explain how the community participated in choosing the area to be nominated and why the area was nominated;

(6) Provide evidence that key participants have the capacity to implement the plan. ${ }^{37}$

To respond to these questions, state and local governments went to considerable effort to include a broad range of participants in the planning process. In New York, more than 2,000 people $(1,100$ in Harlem, 1,000 in the South Bronx) participated in community meetings, town hall meetings, working groups, and open house meeting sessions to provide input 
on the city's strategic plan. ${ }^{58}$ In Philadelphia, 1,500 residents in 450 planning meetings participated in putting together the city's joint application with Camden, New Jersey. ${ }^{59}$ Chicago held similar planning meetings but opened the process from the very beginning and allowed community groups to have significant input in choosing the areas within the city to nominate for the zone designation. ${ }^{60}$

Although the actual level of participation probably varied among the cities that were successful in winning zone designation, all produced comprehensive strategic plans and an impressive array of public and private commitments. By all accounts, Detroit's was the most spectacular in terms of private support. General Motors Corp. pledged $\$ 8$ million for the creation of a development fund; offered to transfer its Cadillac Engineering Building and adjacent emissions laboratory and parking lot (valued at $\$ 5$ million) to the Detroit public schools for use as a vocational and technical education center in the zone; and promised to make $\$ 50$ million in purchases from minority companies in the zone, build a multi-hundred million-dollar manufacturing facility expected to create more than 500 jobs, and establish a multimillion-dollar "value-added" assembly operation within the zone. Major utilities promised to expand service and, in some cases, reduce monthly bills in the empowerment zone. A consortium of banks and financial institutions committed $\$ 1$ billion to empowerment zone investments over ten years and pledged to provide technical assistance and apply liberalized lending criteria for new zone businesses. ${ }^{61}$ Insurance companies offered to look for ways to provide affordable personal and commercial insurance coverage. Leading accounting and law firms agreed to discount their services by as much as 75 percent for businesses and nonprofit organizations in the empowerment zone. A consortium of universities-Wayne State, Michigan State, and the University of Michigan-agreed to focus resources of multiple departments on the target area. A local television station agreed to produce segments describing lending and job-training programs and the local press pledged a weekly bulletin board. ${ }^{62}$

More than 500 applications were submitted for empowerment zone and enterprise community status. The applications also included 1,200 requests for waivers of federal regulations in connection with housing, community development, education, environmental issues, and other areas. ${ }^{63}$ The final zone designation decisions were based on the effectiveness of the strategic plan, the assurances provided and additional criteria specified by each Secretary. ${ }^{64}$ The cities chosen as Urban Empowerment Zones are:

Atlanta, GA

Chicago, IL

Baltimore, MD

Detroit, MI 
Harlem/Washington Heights/South Bronx, NY

Philadelphia, PA/Camden, NJ

The cities and related counties with areas designated as Enterprise Communities are:

Birmingham, AL

Phoenix, AZ

Little Rock/Pulaski County, AR

Los Angeles/Huntington Park, CA

San Diego, CA

San Francisco/Bayview/Hunters Point, CA

City \& County of Denver, $\mathrm{CO}$

Bridgeport, CT

New Haven, $C T$

Wilmington/New Castle County, DE

Dade County/Miami, FL

Tampa, FL

Albany, GA

East St. Louis, IL

Springfield, IL

Indianapolis, IN

Des Moines, IA

Louisville, KY

New Orleans, LA

Ouachita Parish, LA

Lowell, MA

Springfield, MA

Flint, MI

Muskegon, MI

Minneapolis, $\mathrm{MN}$

St. Paul, MN

Jackson, MS

St. Louis/St. Louis County/ Wellston, MO

Omaha, NE

\author{
Clarke County/Las Vegas, NV \\ Manchester, NH \\ Newark, NJ \\ Albuquerque, NM \\ Albany/Schenectady/Troy, NY \\ Buffalo, NY \\ Newburgh/Kingston, NY \\ Rochester, NY \\ Charlotte, NC \\ Akron, $\mathrm{OH}$ \\ Columbus, $\mathrm{OH}$ \\ Oklahoma City, OK \\ Portland, OR \\ Harrisburg, PA \\ Pittsburgh \& Allegheny County, \\ PA \\ Providence, RI \\ Charleston, SC \\ Memphis/Shelby County, TN \\ Nashville/Davidson, TN \\ Dallas, TX \\ El Paso, TX \\ San Antonio, TX \\ Waco, TX \\ Ogden, UT \\ Burlington, VT \\ Norfolk, VA \\ Seattle, WA \\ Tacoma, WA \\ Huntington, WV \\ Milwaukee, WI \\ Washington, DC
}

Empowerment zone and enterprise community designations last for ten years, but the Secretary of HUD or Agriculture may revoke the designation earlier if the state or local government changes the zone or community boundaries or fails to comply with or make progress in achieving the benchmarks set forth in the strategic plan. ${ }^{65}$ Zones and communities are required to make periodic reports about actions that have been taken in accordance with the strategic plan and HUD will conduct periodic on-site 
performance reviews to evaluate the plan's progress. ${ }^{\text {6h }}$ Some groups have requested that the standards for citizen participation for any strategic plan revisions be the same as those required for initial strategic plan development. HUD has promised to consider this suggestion in future rulemaking. ${ }^{67}$

Surprisingly, Los Angeles, the city whose urban problems brought enterprise zones to national prominence, was not chosen for empowerment zone status. Apparently, its application did not measure up to the quality and level of coherence and commitment found in other applications. ${ }^{68}$ The city's failure to win zone designation highlights a negative aspect of the competitive process. By allocating funds based on performance in the process rather than on greatest need, the competitive process may fail to serve the interests of residents in the most distressed communities. The reality is, however, that in this time of limited or shrinking budgets, hard choices must be made in some manner. Moreover, this critique has to be balanced with the fact that the process of strategic, albeit competitive, planning has itself become one of the benefits of the empowerment zone program. To the extent Los Angeles failed to take full advantage of the strategic planning process, the community was deprived of a key innovative aspect of the program.

Following zone designation, both Los Angeles and Cleveland, Ohio, were given a consolation prize and named Supplemental Empowerment Zones, eligible to receive grants under HUD's economic development initiative program, "which enables communities to provide financing for economic development, housing rehabilitation, and essential development projects. ${ }^{169}$ In addition, four other applicants were named Enhanced Enterprise Communities-Oakland, California; Boston, Massachusetts; Kansas City, Missouri and Kansas; and Houston, Texas-also eligible for certain benefits. ${ }^{\text {To }}$

\section{Evaluating the Success of Empowerment Zones}

As the empowerment zone and enterprise community programs move forward, the public likely will evaluate their success in terms of the rather narrow issue of job creation. During the competitive application process, applicants for zone status made optimistic pledges that thousands of jobs would be created as a result of the public and private commitments received. Although few believe that tax incentives will be the most important factor in a business's decision to operate within an empowerment zone, some jobs will certainly be created because of the overall package of program benefits. Because this aspect of empowerment zones is so prominent, it is important to understand that job creation within designated zones will not necessarily lead to employment of zone residents. A recent study conducted in the Red Hook section of Brooklyn, New York, suggests that job creation in distressed neighborhoods does not guarantee a significant increase in neighborhood employment."

According to the authors, the absence of social networks to provide 
entry into the job market, rather than the lack of nearby jobs, is a significant reason for ghetto unemployment: "Red Hook's mix of industry and impoverishment seems to confound the logic behind enterprise zones. Numerous manufacturing plants and jobs exist in a neighborhood with high levels of poverty, unemployment and crime. ${ }^{\prime 72}$ A survey of local employers revealed that, although racial and ethnic stereotypes played a part in this pattern, the employers relied primarily on personal referral or social networks to find employees. As a result, Red Hook residents were unable to obtain jobs in their own neighborhood. The authors noted, however, that this pattern could be overcome by creating proxy networks. A community organization, the South Brooklyn Local Development Corporation, established a screening and referral service to inform, socialize, and vouch for employees in a way similar to that of social and ethnic networks.

Empowerment zone legislation attempts to ensure that residents will benefit from business location in their communities by requiring that zone businesses employ at least 35 percent zone residents to qualify for tax incentives. ${ }^{73}$ Over the long term, to generate employment opportunities beyond the 35 percent minimum and, moreover, encourage businesses operating outside of empowerment zones to hire zone residents, access to social networks for support and referral must be enhanced. Bridging the social gap will require significant hands-on efforts by local community organizations.

In attempting to broaden employment opportunities for zone residents, the failure to extend employment tax credits to firms operating outside empowerment zones may have been shortsighted. Although the rationale that zone benefits should encourage businesses to invest physically within the zones is sound, it ignores the mobile American work pattern of commuting. Still, in light of the fact that the entire zone program is an effort to reverse the disinvestment in urban areas over the past twenty-five years, perhaps fully committing the program resources to businesses operating in the designated areas is a sound approach, at least initially.

Rather than focusing solely on the number of jobs created, an alternative measure of success will be the catalytic effect the program is likely to have on investment in human, economic, and community development within the zones and the willingness to experiment and branch out from traditional patterns and practices. The intangible benefits of the strategic planning and collaboration process and the increased visibility resulting from zone status are likely to generate new and creative approaches to addressing community problems, which may be viable alternatives for revitalizing communities. It will be interesting to see how all of the disparate elements of a community that came together to advance the common goal of winning designation will handle the difficult task of deciding exactly how the zone's money will be allocated. In New York City, community members have offered differing ideas as to which programs should take priority, ranging from small business assistance projects, to improving computer training in public schools, to creating a computerized global 
marketing system, to restoring the blighted Bronx Terminal Market and reviving an industrial rail yard tract in the South Bronx. ${ }^{74}$

It also will be fascinating to see how different groups within communities, especially merchants already operating within the zones, will respond to the introduction of large, established companies, such as chain supermarkets. For example, a proposal to construct a large supermarket in East Harlem was only narrowly approved by the local city council following strenuous opposition by the largely Latino bodega owners. The council member who cast the deciding vote decided that the poor residents, both Latino and African-American, would benefit from access to jobs and better services. $^{75}$

Similarly, Baltimore is planning to renovate an existing market and demolish a portion of another marketplace to construct a supermarket and to create small business opportunities for the mostly African-American residents of the neighborhood. ${ }^{76}$ These efforts threaten, however, to displace the Korean merchants who have been operating in the markets for years but were largely uninvolved in the strategic planning process. Although resolving the interests of merchants and residents will test the mettle of local government, the potential to draw a more economically prosperous group into a community in which they have operated as outsiders is one of the benefits that could not be foreseen at the outset of the empowerment zone endeavor. The first stages of the process present the promise that other elements of these communities will be inspired to participate in future development efforts.

Although the empowerment zone emphasis on community participation is commendable, an important question remains-whether participation by poor residents in the ongoing planning process has been and will be significant and meaningful. The authors of a book chronicling the organization and revitalization of a Boston neighborhood argue that community resident participation in public-private partnerships or certain community development organizations is not necessarily meaningful.

[I]n most cases ..., "public-private partnerships," in which representatives from low-income neighborhoods are asked to sit at the table with government, business and other private sector leaders, have led to little gain for the community and sometimes great harm. Sitting at the table is not the same as exercising community power... . To forge an effective partnership, the community must be organized well enough to be an equal partner at the table... . The community must be perceived as bringing resources to the table, not necessarily financial, but principally the power to create political will and the vision of how the future should be shaped. The community must be respected by those involved. Their ideas and perspectives must be valued by the participants.

Because local community development organizations create and drive local development and revitalization, part of the success of these efforts will have to be based on the extent of community representation, participation, and influence in these organizations. This requires that local prac- 
titioners ask themselves whether their projects contribute to, hinder, or fail to adequately promote community involvement and empowerment.

\section{The Program's Potential}

The empowerment zone program has been heralded as perhaps "Washington's last great urban initiative. ${ }^{\text {"78 }}$ While it is easy to focus on what empowerment zones are not, it is more productive to focus on their potential. After more than a decade of urban disinvestment, scapegoating of the poor and disadvantaged, and increasing urban poverty, empowerment zones represent an informed effort by the federal government to lend a guiding and supportive, rather than restrictive, hand to local community development. The empowerment zone program promises to stimulate and support in unprecedented fashion, creative planning and development by local governments, citizens, and organizations. At the very least, the competitive application process required local governments, community activists, residents, and corporations to come together and collectively identify local urban problems and attempt to devise solutions.

In the short term, the real success of the empowerment zone program is likely to be at the federal policy-making and implementation level. The program has been a dramatic demonstration of the possibilities for innovation by and coordination among federal agencies, an oft-pursued but elusive goal. In the long run, the most promising outcome of this program will not necessarily be that jobs were created or service delivery enhanced, but rather, that local residents were engaged in the process of revitalizing their own neighborhoods. Once hopes are raised and residents are engaged, whether nominally or fully in the planning process, a galvanized constituency may emerge that can work collectively with local government, businesses, and community activists to ensure that residents continue to be included in the process. As envisioned by the term "empowerment zone," it is to be hoped that residents will be enabled to take their rightful place in the process, thereby obtaining their rightful share of economic and political rights and attendant responsibilities.

1. WebSter's ThiRd New INTERNational Dictionary of the ENGLISH LaNGUAGE 757 (unabridged) (1971).

2. Id. at 744 .

3. Revenue Reconciliation Act of 1993, Title XIII of the Omnibus Budget Reconciliation Act of 1993, Pub. L. No. 103-66, $\S \S 13301-13303,107$ Stat. 312, 543 (codified at 26 U.S.C. $\$ \S 1391-1394,1396$, and 1397 (1993)).

4. 26 U.S.C.A. \& 1391(b) (West Supp. 1994). See infra pp. 49-50 for a list of the cities with neighborhoods awarded urban empowerment zone and enterprise community status.

5. 26 U.S.C.A. \& 1391(b).

6. Id. $\$ 1392(a)(2)$. 
7. Id. $\S 1392(\mathrm{a})(1)(\mathrm{A})(3)(\mathrm{A})$.

8. Id. $\S 1391(\mathrm{~b})(2)$.

9. Id. $\$ 1392(\mathrm{a})(1)(\mathrm{B}),(3)(\mathrm{A})$. A number of communities complained during the expedited rulemaking process that the area and population requirements were unduly restrictive for certain sprawling urban and rural areas that would otherwise qualify. Since the requirements were written into law, neither HUD nor USDA was able to alter them. HUD Final Rule, 60 Fed. Reg. 3034, 3036 (1995); USDA Final Rule, 60 Fed. Reg. 6945, 6948 (1995).

10. 42 U.S.C.A. \$ 1397f(a)(2) (West Supp. 1994).

11. Stuart M. Butler, The Conceptual Evolution of Enterprise Zones, in ENTERPRISE ZONES: New DiRECTIONS IN ECoNomic DEVELOPMENT 27, 28 (Roy E. Green ed., 1991) [hereinafter ENTERPRISE ZONES].

12. Id. at 30 .

13. Id. at 39.

14. Enterprise Zone Development, Title VII of the Housing and Community Development Act of 1987, Pub. L. No. 100-242, 101 Stat. 1815 (1988).

15. Rodney A. Erickson \& Susan W. Friedman, Comparative Dimensions of State Enterprise Zone Policies, in ENTERPRISE ZoNes, supra note 11, at 155, 155.

16. Enid Beaumont, Enterprise Zones and Federalism, in ENTERPRIse ZONES, supra note 11 , at 41,43 .

17. Telephone Interview with Richard Cowden, Director, American Association of Enterprise Zones (Apr. 25, 1995). Cowden does not include states such as Louisiana and Florida that have regional tax incentive programs that do not conform strictly to the common understanding of what constitutes an enterprise zone. Another state not counted, Kansas, expanded its "enterprise zone" program to encompass the entire state.

18. See Beaumont, supra note 16 , at 47.

19. Revenue Act of 1992, H.R. 11, 102d Cong., 2d Sess. (1992). For a discussion of the enterprise zone provisions of the bill, see H.R. Conf. REP. No. 1034, 102d Cong., 2d Sess. $690-725$ (1992).

20. Duane A. Martin, The President and the Cities: Clinton's Urban Aid Agenda, 26 URB. Law. 99, 115 (citing David Stoesz, Poor Policy: The Legacy of the Kemer Commission for Social Welfare, 71 N.C. L. REv. 1675, 1687 (1993)). For a detailed description of the provisions of the 1992 bill, see Ellen P. Aprill, Caution: Enterprise Zones, 66 S. CAL. L. Rev. 1341, 1342 n.8 (1993).

21. The other major components of the Clinton urban agenda, also passed in OBRA, are a Community Development Financial Institutions (CDFI) Fund and expansion of the Community Development Block Grant (CDBG) program. These two components may be in jeopardy, however. In March 1995 the House of Representatives passed rescission legislation that would eliminate all appropriations for the CDFI Fund and severely reduce the CDBG program. H.R. 1158, 104th Cong., 1st Sess. (1995); 141 Cong. REc. H3303 (daily ed. Mar. 16, 1995).

22. Empowerment zones, as finally adopted in OBRA, differed from the vetoed 1992 enterprise zone legislation in a number of respects including: (1) exclusion of the capital gains provision; (2) the addition of substantial social services block grants; (3) exclusion of Indian reservations from the program (given alternative incentives elsewhere in OBRA); and (4) enhancement of the application process to include more specific and comprehensive requirements for strategic planning by applicants. 
23. Frederic L. Ballard, Jr. \& Linda B. Schakel, Special Report-EZ Bonds Will Not Be Easy, in CurRent Develorments in Tax Rules for Municipal. FINANCE, PLI Real Est. L. Practice Course Handbook Series, 1995 available in WL, $408 \mathrm{PLI} /$ Real 839 (pagination unavailable). For the general rules governing tax-exempt, private activity bonds, see 26 U.S.C.A. $\$ \S 103,141-150$ (1988).

24. 26 U.S.C.A. \& 1394(c) (West Supp. 1994).

25. Id. \& 146 .

26. Designation of Rural Empowerment Zones and Enterprise Communities, USDA, 60 Fed. Reg. 6945 (1995).

27. 26 U.S.C.A. $\& 1396$ (b) (West Supp. 1994). The empowerment zone wage credit is coordinated with the section 51 targeted jobs wage credit that expired at the end of 1994 and allowed employers to deduct $40 \%$ of the first year's wages, up to $\$ 6,000$, paid to certain targeted persons with traditionally high unemployment including, inter alia, economically disadvantaged youths, Vietnam Vets, disabled persons and ex-convicts. 26 U.S.C.A. \$ 51(a)-(d). If an empowerment zone employee qualifies an employer for both credits during 1994 , the targeted jobs $40 \%$ credit should apply to the first $\$ 6,000$ in wages and the $20 \%$ empowerment zone wage credit would apply to the next $\$ 9,000$ of wages. The maximum potential wage credit would then be $\$ 4,200$ for the first year of employment. Id. $\S 1396$ (c)(3) (West Supp. 1994). Since empowerment zone designations were not made until early 1995, only employers operating within empowerment zones prior to 1995 will benefit from both credits.

28. 26 U.S.C.A. $\S 1397(a)(2)$ (West Supp. 1994).

29. Adam M. Handler, Empowerment Zones and Other Business Incentives May Provide Only Limited Bentefits, 79 J. TAX'N, 274, 275 (1993) (citing 26 U.S.C. § $280 \mathrm{C}(\mathrm{a}))$.

30. 26 U.S.C.A. $\$ \S 179,1397 A, 1397$ C (West Supp. 1994). Handler, supra note 29 at 275 .

31. 26 U.S.C.A. \& 1397C(a) (West Supp. 1994).

32. Id. $\S 1397 \mathrm{~B}(\mathrm{~b})$. Individual proprietorships are relieved of this requirement. Id. $\S 1397 \mathrm{~B}$ (c) (distinguishing proprietorships from business entities).

33. Id. $\$ 1397 \mathrm{~B}(\mathrm{~b})$. As discussed infra, limiting wage credits to zone businesses may be one of the more unfortunate aspects of the empowerment zone legislation because it restricts the program's potential to provide zone residents with increased employment opportunities.

34. Id. § $1397 \mathrm{~B}(\mathrm{~d})(2)$.

35. Id.

36. Id. § 1397B(d)(5).

37. Notice of Request for Consideration for Community Development Corporation Designation, 59 Fed. Reg. 13,582 (1994).

38. U.S. Dep't of HUD, News Release No. 94-94, 20 Community Development Corporations Selected to Receive Tax Credits for Urban/Rural Revitalization (June 30, 1994). The Revenue Reconciliation Act of 1993, Pub. L. No. 103-66, $\S 13311(e)(2), 107$ Stat. 312, 557 (1993) (reprinted at 26 U.S.C.A. $\S 38$ note (West. Supp. 1994)).

39. Pub. L. No. 103-66 § 13311(b)-(c).

40. Id. \$13311(d)(1)(D).

41. Id. \& 13311(d)(2).

42. Id. \$13311(f). 
43. Notice of Request for Consideration for Community Development Corporation Designation, 59 Fed. Reg. 13,582, 13,583 (1994).

44. 42 U.S.C.A. $\$ 1397 f(a)$ (West Supp. 1994). For those zones encompassing more than one state, grants are allocated based on the portion of zone population residing in each state.

45. Dep't of HUD Final Rule, Designation of Empowerment Zones and Enterprise Communities, 60 Fed. Reg. 3034, 3041 (1994) (to be codified at 24 C.F.R. $\$ 597.200(d)(12)(i i)(A)-(C))$.

46. Id.; 42 U.S.C.A. \& 1397f(b)-(c) (West Supp. 1994).

47. 60 Fed. Reg. 3034, 3041 (1994) (to be codified at 24 C.F.R. $\S$ $597.200(\mathrm{~d})(12)(\mathrm{iii}))$.

48. Id.

49. Id. $\S 597.200(\mathrm{~d})(12)(\mathrm{v})$.

50. Thomas J. Lueck, 3 Empowerment Areas Must Create a Wish List, N.Y. Times, Dec. 27, 1994, at B3.

51. Memorandum Establishing the President's Community Enterprise Board, 29 Weekly Comp. Pres. Doc. 1716 (Sept. 9, 1993).

52. Dep't of Education, Notice of Final Priority, Urban Community Service Program, 60 Fed. Reg. 12,749 (1995).

53. U.S. Dep't of HUD, EmpoWerment Zones \& ENTERPRISE COMMUNitIES Application Guide, BuIlding Communities: Together, HUD-1445-CPD, 34 (Jan. 1994).

54. Statement by President William J. Clinton upon signing S. 2060, Small Business Administration Reauthorization and Amendments Act of 1994, Pub. L. No. 403, 103d Cong., 2d Sess. (1994), 30 Weekly Comp. Pres. Doc. 2151 (Oct. 22, 1994).

55. 60 Fed. Reg. 3034, 3040-41 (1995) (to be codified at 24 C.F.R. $\S$ $597.200(c))$.

56. U.S. Dep't of HUD, Guidebook for Community-Based Strategic Planning for Empowerment Zones and Enterprise Communities, Building COMMUNITIES TOGETHER, HUD-1443-CPD, 6 (Jan. 1994).

57. 60 Fed. Reg. 3034, 3041 (1995) (to be codified at 24 C.F.R. $\$ 597.200$ (d)).

58. New York City Empowerment Zone Application Executive Summary (on file with author).

59. Neil R. Pierce, The Power of Empowerment Zones, 27 Nat'L J. 315 (1995).

60. Chicago Empowerment Zone Application Executive Summary (on file with author).

61. Detroit Empowerment Zone Application Executive Summary (on file with author). A newspaper account provides an inside view of how this billiondollar commitment was put together. Brenda Schneider, a community reinvestment manager for Comerica worked twelve-hour days, often six or seven days a week, for six months to bring rival Detroit banks together for the commitment. Just before the application due date, the commitments were not quite at the $\$ 1$ billion mark and she convinced her bank to make up the difference by adding $\$ 410$ million. According to Schneider, all of the lenders promised to honor the commitments even if Detroit did not receive empowerment zone designation. Lynn Waldsmith, Manager Crafts $\$ 1$ Billion Deal Among Rival Banks, Detrolt News, Feb. 22, 1995, at E1.

62. Pierce, supra note 59.

63. Id. 
64. 26 U.S.C.A. § 1392(c) (West Supp. 1994). At least two areas, Philadelphia and Camden had a statutory advantage in the zone selection process. The statute required one zone to be "designated in an urban area, the most populous city of which has a population of 500,000 or less and no less than 1 [zone] shall be a nominated area which includes areas in two States and which has a population of 50,000 or less." Very few other cities could meet this criteria. Id. \& 1391(b)(2).

65. Id. \& 1391(d).

66. 60 Fed. Reg. 3034, 3044 (1995) (to be codified at 24 C. F.R. $\$ 597.400-.401$ ).

67. Id. at 3037.

68. Pierce, supra note 59.

69. Dep't of HUD, Notice of Designation of Empowerment Zones and Enterprise Communities, 60 Fed. Reg. 10,018 (1995).

70. Id. A8.

71. Philip Kasinitz, The Real Jobs Problem, Wall St. J., Nov. 26, 1993, at

72. Id.

73. 26 U.S.C.A. $\$ 1397 B(b)(6)$, (c)(5) (West Supp. 1994).

74. Lueck, supra note 50.

75. Brett Pulley, East Harlem Supermarket Is Approved, N.Y. Times, Apr. 28, 1995, at B1.

76. Anna Borgman, Plans for Baltimore Market Threaten to Split Blacks, Koreans, WASH. Post, Apr. 23, 1995, at B3.

77. Peter Medoff \& Holly Sklar, Streets of Hope: The Fall and Rise of AN URBAN NEIGHBorhoOd 276 (1994). According to Bill Slotnik, Director of the Community Training and Assistance Center, "[m]ost nonprofits are based in communities, and are not community-based." $I d$. at 256.

78. Pierce, supra note 59. 